\title{
UJI PUBLIK TERHADAP PUTUSAN \\ KASUS ILLEGAL LOGGING A.N. ADELIN LIS DKK
}

\author{
Teguh Soedarsono ${ }^{1}$
}

\begin{abstract}
Straightening of case law illegal logging with defendant on behalf of Adelin Lis and partners which processed the law by District court Medan categorized as controversy decision, phenomenal, and draw attention the public, therefore from in perspective of law, social justice, and intact publication needed by the public test which entangle various credible side and don't related to object which being examined. The ill defined of assertion and demand weaken of verification, existence of functionary intervention and also the law decision items and consideration base which is anticipated have the share in forming practice "Judicial Corruption" to handling of the case is needed to be analysis, careful, and laid open for repair here in after in scope to straightening of law of similar case in Indonesia.
\end{abstract}

Kata kunci: illegal logging, eksaminasi publik, dan produk peradilan hukum kasus Adelin Lis

\section{Pengantar}

Uji Publik atau lebih dikenal dengan "Eksaminasi Publik" terhadap produk peradilan hukum (dakwaan, tuntutan, dan putusan peradilan) mempunyai arti pemeriksaan dan pengujian produk peradilan oleh berbagai pihak yang tidak berkaitan dengan proses maupun produk peradilan yang sedang dieksaminasi. Dengan melakukan uji publik maka secara langsung masyarakat ikut serta memberikan pengawasan dan koreksi langsung terhadap institusi peradilan hukum dalam menjalankan peran dan fungsinya dalam menegakkan kebenaran, keadilan, dan hukum. ${ }^{2}$

Sebenarnya terdapat sejumlah besar proses dan produk peradilan hukum kasus illegal logging yang dinilai kontroversial, fenomenal, dan

1 Penulis adalah Dosen Tetap Program Pascasarjana Studi Ilmu Hukum Universitas 17 Agustus 1945 -Jakarta. Alamat korespondensi: teguh.soedarsono@gmail.com.

${ }^{2}$ J. Djohansyah, "Legal Anotasi Terhadap Putusan Perkara Illegal Logging dengan Terdakwa Adelin Lis", Jakarta, 2008, hal.1. 
menarik perhatian publik, namun dalam media saat ini akan diulas tentang proses dan produk peradilan hukum dalam kasus tindak pidana illegal logging dengan terdakwa An. Adelin Lis dkk yang diproses hukum oleh Pengadilan Negeri Medan dengan berkas putusannya Nomor: 2240/Pid.B/2007/PN.MDN tanggal 5 Nopember 2007.

Beberapa bagian awal tentang kajian ini sudah dilakukan oleh berbagai pihak dengan rumusan-rumusan penting yang dapat dijadikan masukan dalam proses penegakan hukum dalam kasus yang sama, namun terhadap hasil kajian tersebut kurang sekali didukung dengan publikasi yang utuh sehingga masyarakat sering kurang mempercayai hasil eksaminasi internal yang telah dilakukan oleh berbagai pihak tersebut.

Uji publik ini bertujuan memberikan pengkritisan, penilaian dan koreksi secara obyektif terhadap produk peradilan hukum Pengadilan Negeri Medan beserta ekstrak putusan proses peradilan Kasasi Mahkamah Agung dalam perkara tindak pidana illegal logging dengan terdakwa Adelin Lis dkk.

Berbagai hal yang ditenggarai bermasalah terhadap produk dakwaan dan tuntutan hukum yang oleh pihak Penuntut Umum, dan proses pertimbangan hukum serta putusan Majelis Hakim atas kasus tindak pidana tersebut yang terkesan menampikkan azas dan kewajiban hukum formil akan dilakukan, walaupun dalam hal ini terdapat aspek independensi dan imparsialitas Hakim sebagai koridor dan benteng dalam pelaksanaan peran dan hasil kerjanya tersebut.

Di sisi lain dalam proses peradilan hukum kasus tindak pidana ini tercium aroma pelanggaran Code of Conduct atau Yudicial Corruption oleh para hakim dalam menangani kasus perkara ini, ${ }^{3}$ bahkan adanya intervensi Menteri Kehutanan pada saat proses peradilan hukum berjalan telah memberikan andil yang cukup besar dalam proses pertimbangan hukum dan pembuatan produk keputusan Pengadilan Negeri Medan terhadap kasus perkara tersebut. Majelis Kasasi dalam proses peradilan kasus perkara tindak pidana ini oleh Mahkamah Agung tersebut telah menyatakan bahwa terdakwa Adelin Lis dkk selain terbukti telah melakukan tindak pidana illegal logging seperti diatur dalam Undang-undang Nomor 41 tahun 1999 tentang Kehutanan juga terbukti memenuhi unsur norma dalam Undangundang Nomor 31 tahun 1999 juncto Undang-undang Nomor 20 tahun 2001 tentang Pemberantasan Tindak Pidana Korupsi yang bila didasarkan pada azas Concursus idealis terhadap terdakwa dapat diancam hukuman yang terberat dalam norma ketentuan hukum tentang Pemberantasan Korupsi.

${ }^{3}$ KY Rekomendasi Majelis hakim yang menangani kasus Adelin Lis dijatuhi Sanksi, $<$ http:/www.hukumonline.com/detail.asp?id=19839\&cl=Berita $>$, diakses tanggal 5 Desember 2007, 
Uji publik ini dilakukan secara terbuka, kritis, dan ilmiah sehingga produk kajian, materi pengkritisan, dan berbagai rekomendasinya dilakukan secara objektif, nalar, dan dapat ditindaklanjuti untuk kepentingan selanjutnya oleh berbagai pihak yang bersangkutan.

Proses uji publik ini selain dilakukan aktivitas diskusi publik dan diskusi terfokus, juga dilakukan aktivitas pembahasan yang melibatkan berbagai praktisi hukum, akademisi, peneliti, dan aktivis lingkungan yang kapasitas maupun kredibilitasnya sudah tidak diragukan lagi.

\section{Analisis Hukum}

\section{A. Kasus Posisi}

Terdakwa An. Adelin Lis (42 tahun) bekerja di PT. Keang Nam Development Indonesia (PT. KNDI) sebagai Direktur Umum dan Keuangan; yang bersama-sama dengan Ir. Oscar A Sipayung (Direktur Utama PT. KNDI) dan Ir. Washington Pane (Direktur Perencanaan dan Produksi PT. KNDI) beraktivitas melakukan joint venture dengan PT. Mujur Timber yang bergerak di bidang usaha pemanfaatan hasil hutan di daerah Kecamatan Muara Batang Gadis - Kebupaten Mandailing Natal - Propinsi Sumatera Utara dengan berdasarkan Surat Keputusan Menteri Kehutanan dan Perkebunan Republik Indonesia Nomor : 805/Kpts-VI/1999 tanggal 30 September 1999 untuk masa waktu 55 tahun yang dihitung berlaku surut sejak tahun 1994 untuk lahan hutan seluas 58.590 Hektar. Dalam operasional penebangan tegakan pohon dan disamping itu mereka pemanfaatan hasil hutan kayu yang berdasarkan surat ijin tersebut, ternyata PT. KNDI terbukti telah melakukan praktek illegal logging berupa penebangan tegakan pohon di luar areal Rencana Kerja Tahunan (RKT) yang telah ditentukan dan disyahkan oleh pihak pemerintah yang berwajib, dan tidak membayar Provisi Sumber Daya Hutan (PSDH) maupun Dana Reboisasi (DR) yang diwajibkan baginya seperti yang terinventarisasi pada tabel berikut ini: ${ }^{4}$

${ }^{4}$ Data hasil rekonstruksi lapangan yang dilakukan oleh Dinas Kehutanan Sumatera Utara dan pihak Polda Sumut. 
Tabel 1

Rekonstruksi Lapangan Atas Lokasi Penebangan PT.KNDI ${ }^{5}$

\begin{tabular}{|c|c|c|c|c|}
\hline \multirow{2}{*}{ Tahun } & \multirow{2}{*}{ Lokasi/Koordinat } & \multicolumn{2}{|c|}{ Volume Tebangan } & \multirow{2}{*}{ Keterangan } \\
\hline & & Batang & Meter Kubik & \\
\hline 2000 & $\begin{array}{l}00^{\circ} 57^{\prime} 22,4 \text { ' } \mathrm{LU} \text { dan } 99^{\circ} 03^{\prime} \\
26,4^{\prime} \text { 'BT } \\
\text { (Jalan Danau Km 10, di luar } \\
\text { RKT) } \\
\text { Jalan Danau Km } 12 \text { di luar RKT }\end{array}$ & 15.544 & $37.608,65$ & $\begin{array}{l}\text { Tanpa } \\
\text { PSDH dan } \\
\text { DR }\end{array}$ \\
\hline 2001 & $\begin{array}{l}00^{\circ} 55^{\prime} 06,9^{\prime} \text { ' LU dan } 99^{\circ} 07^{\prime} \\
09,0^{\prime \prime} \mathrm{BT} \\
\text { (Jalan Koridor Km 9) }\end{array}$ & 14.697 & $24.090,15$ & $\begin{array}{l}\text { Tanpa } \\
\text { PSDH dan } \\
\text { DR }\end{array}$ \\
\hline 2002 & $\begin{array}{l}00^{\circ} 54^{\prime} 55,6^{\prime} \text { ' LU dan } 99^{\circ} 06^{\prime} \\
55,4^{\prime \prime} \text { BT } \\
\text { (Jalan Koridor } \mathrm{Km} \mathrm{9,} \mathrm{di} \mathrm{luar} \\
\text { RKT) }\end{array}$ & 23.310 & $55.451,32$ & $\begin{array}{l}\text { Tanpa } \\
\text { PSDH dan } \\
\text { DR }\end{array}$ \\
\hline 2003 & $\begin{array}{l}00^{\circ} 55^{\prime}, 30,8^{\prime \prime} \text { LU dan } 99^{\circ} 04^{\prime} \\
25,3^{\prime \prime} \mathrm{BT}\end{array}$ & 7.916 & $20.659,73$ & $\begin{array}{l}\text { Tanpa } \\
\text { PSDH dan }\end{array}$ \\
\hline 2004 & $\begin{array}{l}\text { (Jalan Danau Km 4, di luar } \\
\text { RKT) }\end{array}$ & 10.750 & $26.652,76$ & $\begin{array}{c}\text { DR } \\
\text { Tanpa } \\
\text { PSDH dan } \\
\text { DR }\end{array}$ \\
\hline 2005 & $\begin{array}{l}00^{\circ} 56^{\prime} 50,4^{\prime \prime} \text { LU dan } 99^{\circ} 05^{\prime} \\
21,2 \text { 'BT } \\
\text { (Jalan Danau Km 9, di luar } \\
\text { RKT) }\end{array}$ & 12.776 & $24.788,32$ & $\begin{array}{l}\text { Tanpa } \\
\text { PSDH dan } \\
\text { DR }\end{array}$ \\
\hline
\end{tabular}

Akibat dari aktivitas PT.KNDI tersebut berakibat terjadinya perubahan tutupan hutan yang cukup luas dan telah mengindikasikan terjadi deforestasi di dalam dan luar UPHHK atau konsensi wilayah PT.KNDI yang dapat berdampak terjadinya bencana alam yang luar biasa bagi daerah tersebut dan sekitarnya.

1. Analisis terhadap Produk Peradilan Hukumnya.

Bentuk Surat Dakwaan terhadap kasus ini dikonstruksikan secara kombinasi, yaitu menggabungkan beberapa dakwaan secara komulatif dan alternatif, yang dalam hal ini:

${ }^{5}$ Putusan Pengadilan Negeri Medan Nomor: 2240/Pid.B/2007/PN.MDN tanggal 5 Nopember 2007. 
- Pada "Dakwaan Kesatu Primair", Jaksa Penuntut Umum (JPU) mendakwakan dengan Pasal 2 ayat (1) juncto Pasal 18 Undang-undang Nomor 31 tahun 1999 tentang Pemberantasan Tindak Pidana Korupsi (sebagaimana telah ditambah dan diubah dengan Undang-undang Nomor 20 tahun 2001) juncto Pasal 55 ayat (1) dan Pasal 64 ayat (1) KUHP;

- Sedangkan pada "Dakwaan Kedua Primair", JPU mendakwakan dengan Pasal 50 ayat (2) juncto Pasal 78 ayat (1) dan ayat (4) Undang-undang Nomor 41 tahun 1999 tentang Kehutanan (sebagaimana telah ditambah dan diubah dengan Undang-undang Nomor 19 tahun 2004) juncto Pasal 64 ayat (1) KUHP.

Dari kedua dakwaan tersebut yang paling krusial adalah "Dakwaan Kesatu Primair" yang mendakwakan terdakwa telah melanggar Pasal 2 ayat (1) Undang-undang Nomor 31 tahun 1999 juncto Undangundang Nomor 20 tahun 2001, dan "Dakwaan Kedua Primair" yang mendakwakan melanggar Pasal 50 ayat (2) juncto Pasal 78 ayat (1) Undang-undang Nomor 41 tahun 1999 juncto Undang-undang Nomor 19 tahun 2007.

Dalam hal ini JPU berusaha membuktikan semua dakwaan dalam sebuah "Dakwaan yang bersifat komulatif", atau secara Concursus Comulative $e^{6}$ terhadap aktivitas perbuatan tindak pidananya maupun para pelakunya dengan satu karakteristik yang dapat diyakininya nyata-nyata merupakan subjek dan atau objek hukum pidananya.

2. Pertimbangan dan Keputusan Majelis Hakim PN. Medan.

- Dalam proses pertimbangan hukum terhadap surat dakwaan JPU, Majelis Hakim berpendapat bahwa materi dakwaan JPU merupakan Lex specialis derogate Lex generalis, dalam hal ini Undang-undang tentang Kehutanan harus diterapkan sebagai Lex specialis dalam kasus perkara ini;

- Dakwaan bahwa terdakwa dengan PT. KNDI yang melakukan penebangan tegakan pohon dan memungut hasil hutan kayu di luar areal Rencana Kerja Tahunan tidak dapat dibuktikan karena tidak disertai bukti, sehingga atas perbuatan tersebut hanya dapat dikategorikan sebagai bentuk

6 Harun M. Husein, "Surat Dakwaan: Teknik Penyusunan, Fungsi, dan Permasalahan", (Jakarta: Rineka Cipta, 2009), hal. 80-81. 
"pelanggaran administrasi" terlebih terdakwa masih mempunyai ijin HPH di lokasi kawasan hutan yang masih berlaku;

- Dakwaan bahwa terdakwa dengan perusahaannya PT. KNDI tidak membayar PSDH dan DR tidak bisa dibuktikan, karena dalam persidangan ternyata terdakwa dapat menunjukkan bukti fotocopy transfer pembayaran PSDH dan DR walaupun secara keseluruhan belum dilunasinya namun terdakwa bersedia untuk melunasinya; dan

- Dakwaan bahwa terdakwa dengan perusahaannya PT. KNDI tidak mengikutsertakan koperasi, lembaga pendidikan, dan BUMD setempat tidak bisa dikabulkan, karena selama ini untuk aktivitas dan proses hukum atas kewajiban tersebut belum ada petunjuk teknisnya.?

3. Analisis Hukum putusan Peradilan Kasasi Mahkamah Agung.

- Menyatakan bahwa PN. Medan telah salah menerapkan hukum, serta tidak melibatkan keterangan Ahli dalam proses analisis hukum dalam persidangannya;

- Menyatakan bahwa segala kewajiban terdakwa dan perusahaannya PT. KNDI yang tidak dilaksanakan tersebut secara imperatif dan konstitutif sudah dapat dikategorikan sebagai "perbuatan melawan hukum" karena hal itu merupakan kewajiban yang harus dilaksanakan oleh setiap aktivitas pengusahaan dan pengelolaan hutan;

- Menyatakan bahwa dakwaan atas pelanggaran terhadap Undang-undang Kehutanan dan Undang-undang Pemberantasan Tindak Pidana Korupsi secara keseluruhan dapat dibuktikan, oleh karena itu Majelis Hakim seyogyanya memilih aturan hukum yang mengancam dengan hukuman pidana yang terberat atas kasus tersebut; dan

- Majelis Kasasi Mahkamah Agung menjatuhkan vonis pidana kepada terdakwa Adelin Lis berupa hukuman penjara 10 tahun, uang pengganti sebesar Rp. 119,82 Milyar subsider 6 bulan penjara, dan denda sebesar Rp. 1 Milyar. ${ }^{8}$

${ }^{7}$ Putusan Pengadilan Negeri Medan Nomor: 2270/Pid.B/2007/PN.MDN tanggal 5 Nopember 2007 An. Terdakwa Adelin Lis.

8 Majelis Kasasi vonnis Adelin Lis 10 tahun, <http:/www.hukumonline.com/ detail.asp?id=19839\&cl=Berita>, diakses tanggal 2 Agustus 2008 . 


\section{B. Metode Penelitian}

Uji publik ini merupakan penelitian hukum empiris dengan menggunakan data primer yang didapatkan dari focus group discussion (FGD) dan diskusi terfokus serta data sekunder yang ditelusuri melalui literatur kepustakaan serta berbagai peraturan perundang-undangan yang bersangkutan dengan objek penelitian ini, sehingga kajian hukumnya banyak menggunakan pendekatan statuta (statuta approach) dan pendekatan sosiologi hukum (sociolegal approach), oleh karena itu analisis hukumnya dinyatakan dalam bentuk uraian deskriptif kualitatif yang didukung dengan analisis kuantitatifnya terbatas.

\section{Hasil Uji Publik Dan Pembahasannya}

4. Kajian terhadap proses dan produk dakwaan hukumnya, dinyatakan sebagai berikut:

- Dakwaan komulatif yang bersifat concurcus idealis menurut Pasal 63 ayat (1) KUHP harus memenuhi karakteristik terminologi "aktivitas tindak pidananya terbukti melanggar beberapa ketentuan pidana, sehingga terhadap tindak pidana tersebut diberikan satu sanksi hukuman pidana yang terberat", sedangkan menurut Pasal 63 ayat (2) KUHP dinyatakan bahwa "ketentuan hukum yang diberlakukan harus ketentuan yang bersifat khusus dibandingkan ketentuan yang lainnya". Oleh karena itu dakwaan hukum terhadap pelanggaran ketentuan tentang Kehutanan dan ketentuan tentang Tindak Pidana Korupsi merupakan "komulatif concursus" yang tidak dapat diterapkan azas hukum "Lex Specialis Derogat Legi Generali (alternative concursus)", oleh karena itu dalam dakwaan JPU harus membuktikan kedua dakwaan yang diajukan dalam Surat Dakwaannya tersebut karena untuk kasusnya tersebut tidak dapat diterapkan hanya dengan sanksi hukuman pidana yang terberat saja, tetapi sanksi hukum dari kedua ketentuan hukum tersebut harus dikenakan terhadap terdakwa;

- Bentuk, materi, dan konstruksi dakwaan hukum yang dibuat JPU tidak jelas, karena kapasitas terdakwa berkaitan dengan aturan pidana yang didakwakan tidak didukung dengan bukti dan keterangan saksi yang kuat, keterkaitan dan korelasi dakwaan dengan risalah pemeriksaaan tidak bisa tergambarkan secara jelas karena materi perkara yang dinyatakan dalam Surat 
Dakwaan JPU "tidak jelas". Atas hal tersebut terkesan JPU tidak mampu membuat materi dan substansi Surat Dakwaan secara cermat, jelas dan lengkap sesuai ketentuan Pasal 143 ayat (2) KUHAP terhadap tindak pidana yang didakwakan kepada pihak terdakwa An. Adelin Lis dkk tersebut; ${ }^{9}$

- JPU telah meyakini bahwa terdakwa telah melakukan perbuatan tindak pidana melanggar Keputusan Menteri Kehutanan dan Perkebunan Nomor: 805/Kpts-VI/1999 tanggal 30 September 1999 secara berlanjut (Voorgezette Handeling) dari tahun 2000 sampai dengan tahun 2005, namun JPU tidak tegas dalam menentukan posisi terdakwa dari setiap aturan pidana yang didakwakan kepadanya secara khusus dan cermat, ${ }^{10}$ bahkan JPU telah melakukan pendakwaan telah terjadi pelanggaran terhadap UU Kehutanan dan UU Korupsi oleh terdakwa secara komulatif namun terhadap dakwaan komulatif tersebut tidak dibuktikan secara cermat, jelas, dan lengkap sesuai tujuan UU Kehutanan untuk "melindungi dan menciptakan keberlanjutan dalam pemanfaatan hutan negara" maupun UU Korupsi untuk "mengembalikan kerugian dan hilangnya kekayaan Negara";

- Para terdakwa dengan perusahaannya PT. KNDI dalam aktivitasnya melakukan penebangan tegakan pohon dan memungut hasil hutan di kawasan hutan negara dan atas hal tersebut telah meraup kekayaan dari keuangan negara lebih dari Rp. 83 Milyar yang dimasukan ke dalam rekening pribadinya pada Bank Buana dan Bank HSBC, hal ini seyogyanya dijadikan objek hukum dari dakwaan pelanggaran terhadap UU Korupsi yang merupakan aturan khusus (lex specialis) dari KUHP;

Oleh karena itu pendakwaan UU Kehutanan dan UU Korupsi seharusnya dilakukan secara bersama-sama dan tidak memilih salah satunya (alternative cocursus) yang dianggap istimewa. 14-16.

${ }^{9}$ Kejaksaan Agung R.I, "Pedoman Pembuatan Surat Dakwaan", Jakarta, 1985, hal.

${ }^{10}$ Basuki Waris, Dosen Fakultas Kehutanan IPB dalam diskusi terfokus menyatakan bahwa "Apabila perusahaan tidak melaksanakan Tebang Pilih Tanam Indonesia (TPTI), Surat Perintah Pembayaran PSDH dan DR, dan atau membuat laporan hasil produksi kayu bulat termasuk tindak pidana penebangan liar (illegal logging)". 
5. Kajian terhadap pertimbangan dan produk putusan Majelis Hukum, dinyatakan sebagai berikut:

- Pertimbangan bahwa melakukan penebangan kayu dan memungut hasil hutan di luar areal Rencana Kerja Tahunan merupakan pelanggaran yang bersifat administratif dengan sanksi administratif dari Departeman Kehutanan adalah suatu hal yang jauh dari tujuan utama UU kehutanan, karena penerapan ketentuan hukum perundang-undangan kehutanan dalam aktivitas usaha mengelola, memungut hasil hutan, dan mengusahakan hutan pada hakikatnya untuk menjaga hutan dari dampak aktivitas tersebut yang sering memberikan resiko kerusakan, oleh karena itu pelanggaran atas aturan tersebut dikategorikan sebagai "perbuatan melanggar hukum sesuai yang dinyatakan dalam Pasal 1365 KUH Perdata (on recht matig daad).

- Pertimbangan yang menyatakan bahwa dakwaan tidak dilaksanakannya sistem silvikultur TPTI dan penebangan hutan di luar areal RKT merupakan sesuatu hal yang tidak bisa dibuktikan secara faktual sebenarnya karena Majelis Hakim tidak diajak melihat (checking on the spot) wilayah hutan PT. KNDI yang telah menjadi gundul dan terjadi berbagai perubahan fisik yang mengakibatkan kerusakan struktur terhadap tekstur, countur, maupun tanahnya. Keadaan ini dipastikan tidak dapat membuktikan bahwa terdakwa selain telah merusak kondisi hutan alam yang dapat menjadi sumber kerusakan fungsi lingkungan di sekitar wilayah hutan tersebut juga terhadap akibat yang menimbulkan kerugian keuangan negara sehubungan dengan aktivitas tindak pidana pembalakan hutan yang telah dilakukan terdakwa. Atas hal tersebut harus dinyatakan dengan bukti-bukti yang kuat sehingga terdakwa dapat dinyatakan telah melakukan perbuatan melawan hukum yang dapat dikenakan aturan hukum dan sanksi UU Kehutanan maupun UU Korupsi secara komulatif;

- Pertimbangan hukum terhadap tindakan pembalakan liar dan korupsi dalam aktivitas pengelolaan sumberdaya hutan kayu maupun pemanfaatan hasil hutan untuk diarahkan pada hukum dan sanksi administrasi pada hakikatnya merupakan sesuatu pengingkaran dari kewajiban penegak hukum yang disaratkan dalam UU Kehutanan maupun UU Korupsi, terlebih lagi dengan proses hukumnya yang 
mengenyampingkan berbagai keterangan saksi dan ahli yang sangat relevan namun justru menjadikan berbagai keterangan saksi-saksi yang telah mencabut pernyataannya dalam BAP Kepolisian sebagai dasar membuat pertimbangan dan produk materi putusan peradilan di Tingkat Pertama tersebut; dan

- Surat Menteri Kehutanan ${ }^{11}$ yang disampaikan melalui Lawfirm Hotman Paris Hutapea \& Partners yang merupakan kuasa hukum terdakwa dalam proses peradilan hukumnya telah dijadikan dasar pertimbangan hukum Majelis Hakim PN. Medan dalam membuat materi putusan hukum atas kasus illegal logging dengan terdakwa Adelin Lis dkk, sehingga terhadap kasus tindakan pelanggaran hukum tersebut hanya dikenakan norma administrasi dan diberikan sanksi administratif. Keadaan ini jelas kontradiktif dilihat dari keberadaan Menteri Kehutanan yang seharusnya berkontribusi dalam aktivitas perlindungan kawasan hutan dan mengadvokasi pemberantasan praktek pembalakan liar dan korupsi dalam tindak pidana di areal hutan negara secara tegas dan konsisten. Oleh karena itu walaupun pertimbangan Majelis Hakim terhadap tindakan terdakwa Adelin Lis dkk telah dijerat dengan norma dan sanksi administratif, namun atas kasusnya dan akibat hukumnya tidak menghilangkan pertanggunganjawab pidana terdakwa terhadap unsur pidana dalam aturan kehutanan yang dapat terpenuhi, dan di samping itu kearifan Majelis Hakim terhadap masalah lingkungan perlu menjadi perhatian dalam membuat produk materi putusan hukumnya tersebut.

6. Kajian terhadap pertimbangan produk putusan ekstrak peradilan kasasi di Mahkamah Agung, dinyatakan sebagai berikut:

- Pertimbangan hukum atas vonnis Majelis Hakim Pengadilan

Negeri Medan atas kasus perkara tersebut dinyatakan "tidak benar", karena Majelis Hakim pada Peradilan Tingkat Pertama tersebut telah menjadikan Surat Menteri Kehutanan yang kontroversial tersebut sebagai dasar pertimbangan dalam membuat produk materi keputusan hukum perkara tersebut dan ironisnya lagi telah mengenyampingkan keterangan Saksi dan

1 Surat Menteri Kehutanan Nomor: S.613/MenHut-II/2006 tanggal 27 September 2006 yang menyatakan bahwa "Pasal 86 dan Pasal 91 ayat (1) Peraturan Pemerintah Nomor: 24 tahun 2002 merupakan pelanggaran administratif dengan sanksi administrasi dan denda". 
bukti relevan yang sangat diperlukan dalam proses pertimbangan hukumnya;

- Segala kewajiban yang telah ditetapkan dalam norma aturan kehutanan yang meliputi juga aktivitas pengelolaan kawasan hutan pada hakikatnya merupakan kewajiban yang bersifat konstitutif dan imperatif yang harus dilaksanakan, sehingga tidak ada alasan untuk dilalaikan apalagi dikesampingkan karena tidak ada petunjuk yang jelas;

- Norma dan sanksi administratif yang dijatuhkan kepada terdakwa secara hukum tidak akan menghilangkan tanggungjawab pidana terdakwa terhadap berbagai tindakan dan akibat pelanggaran unsur pidana yang dapat dibuktikan, terhadap hal ini untuk selanjutnya dapat menjadi yurisprudensi dalam mengisi celah dan kekosongan hukum dari peraturan tentang kehutanan;

- Peradilan Negeri Medan dinilai rancu dan tidak tepat dalam penggunaan dalil "lex specialis" yang bersangkutan dengan UU Kehutanan, sehingga pertimbangan dan putusan hukumnya mengarah kepada pelanggaran administratif dan vonnis "bebas" terhadap terdakwa. Padahal lex specialis sebenarnya meliputi "lex specialis logic" (Pasal 63 ayat (2) KUHP) dan "lex specialis systemic" (Pasal 63 ayat (1) KUHP), untuk hal ini PN. Medan lebih mengarah pada lex specialis logic dengan menjadikan UU Kehutanan sebagai ketentuan yang bersifat khusus dari UU Korupsi. Hal tersebut tentunya tidak benar, karena kedua ketentuan perundang-undangan tersebut pada dasarnya mengatur materi yang berbeda dengan tujuan yang juga berbeda, dan bahkan kedua peraturan perundang-undangan tersebut sama-sama merupakan "aturan khusus" (lex specialis) dari aturan umum (lex generali) dari KUHP;

Oleh karena itu berdasarkan pertimbangan "concursus idealis" maka UU Kehutanan dan UU Korupsi harus diposisikan sama guna menjerat perbuatan pidana illegal logging secara berbarengan sesuai ketentuan Pasal 63 ayat (1) KUHP; dan

- Dalam menjatuhkan vonis hukum atas kasus tindak pidana tersebut seyogyanya PN. Medan mendasari pertimbangan untuk menggunakan "sistem absorbsi" yang hanya mengenakan satu aturan pidana yang lebih dapat dibuktikan atau mengenakan aturan pidana yang ancaman hukumannya lebih berat dari yang lainnya, oleh karena itu dengan berdasarkan prinsip "concursus idealis" maka atas "Dakwaan Kesatu" (melanggar Pasal 2 ayat 
(1) UU 31 tahun 1999 juncto UU 20 tahun 2001 tentang Tindak Pidana Korupsi) terhadap terdakwa seyogyanya harus dikenakan sanksi hukuman maksimal "seumur hidup atau 20 tahun penjara", karena "Dakwaan Kedua" (melanggar Pasal 50 ayat (1) juncto Pasal 78 ayat (1) dan ayat (14) UU 41 tahun 1999 tentang kehutanan) hanya dapat dikenakan ancaman sanksi hukuman maksimal 10 tahun dan terhadap Badan Hukumnya ditambah sepertiganya (menjadi 13 tahun penjara) saja, sehingga tidak heran bila Majelis Hakim dalam peradilan Kasasi di Mahkamah Agung menjatuhkan vonis hukuman 10 tahun penjara kepada terdakwa atas nama Adelin Lis serta denda dan pembayaran ganti rugi atas hilangnya kekayaan negara tersebut.

\section{Kesimpulan}

Dari hasil kajian, analisis, dan bahasan tersebut di atas, dapat disimpulkan bahwa:

1. Tindak pidana pembalakan liar (illegal logging) selain telah mengakibatkan kerusakan bentang alam, siklus ekologi, dan fungsi lingkungan di kawasan sekitarnya juga telah nyata-nyata merugikan perekonomian serta kekayaan negara yang secara faktual dapat dikategorikan sebagai "Extra Ordinary Crime", oleh karena itu penegakan hukum atas kasus-kasus tindak pidana tersebut harus ditunjang dengan keikutsertaan masyarakat dalam bentuk uji publik terhadap proses maupun produk peradilan hukumnya, terlebih lagi dengan keterbatasan pengetahuan, wawasan, serta kemampuan unsur penegak hukum dalam pelaksanaan peran dan fungsinya untuk mewujudkan maksud dan tujuan setiap norma peraturan perundang-undangan yang bersangkutan;

2. Surat Dakwaan JPU terhadap kasus tindak pidana illegal logging dengan terdakwa An. Adelin Lis dkk dibentuk dalam konstruksi kombinasi antara "Dakwaan Komulatif" dan "Dakwaan Alternatif" dari ketentuan-ketentuan dalam aturan Kehutanan dan aturan Korupsi yang dinyatakan sebagai "lex specialis", namun dalam prosesnya dan produk tuntutannya hanya diarahkan kepada materi dakwaan dari aturan-aturan Kehutanan yang dinilai bersifat khusus, sedang terhadap aturan-aturan lainnya yang bersifat umum tidak ditelaah secara konsisten, sehingga keseluruhan dakwaan hukum atas perkara tersebut terkesan tidak jelas dan 
dinilai rancu terlebih lagi dengan minimnya bukti-bukti serta banyak dicabutnya keterangan para Saksi yang dinilai relevan.

3. Majelis Hakim proses peradilan pertama dari kasus illegal logging dengan terdakwa Adelin Lis dkk ini terkesan menutup mata atas fakta dampak kerusakan lingkungan akibat dari tindak pidana pembalakan hutan tersebut, namun Majelis Hakim lebih mengarahkan pada pertimbangan hukum atas kasus tersebut sebagai pelanggaran administratif dengan sanksi administrasi dan denda semata;

4. Intervensi Menteri Kehutanan dan upaya kontroversial dari kuasa hukum terdakwa yang tidak berwawasan "arief lingkungan" telah memberikan warna dalam proses pertimbangan hukum dan penentuan produk materi putusan peradilan yang menangani kasus perkara tersebut, sehingga kondisi tersebut merajut ke suatu keadaan yang kontroversial, fenomenal, dan mengundang opini publik terhadap hal tersebut;

5. Pertimbangan dan keputusan peradilan kasasi atas kasus ini berkeyakinan bahwa tindak pidana yang dilakukan terdakwa Adelin Lis dkk tidak saja dapat dijerat dengan aturan serta sanksi administrasi, akan tetapi masih dapat juga dijerat dengan aturan serta sanksi pidana dari UU Kehutanan dan UU Korupsi yang memenuhi unsur-unsur hukumnya, oleh karena itu Majelis Hakim Kasasi menerapkan azas concursus idealis dengan menggunakan "sistem absorbsi" yaitu memilih aturan dan ancaman sanksi pidana yang terberat.

\section{Rekomendasi}

Dari kesimpulan hasil uji publik tersebut di atas, bersama ini diajukan beberapa saran untuk tindak lanjutnya antara lain sebagai berikut :

1. Tindak pidana illegal logging merupakan "extra ordinary crime" yang telah memberikan dampak kerusakan bentang alam sehingga tidak mampu lagi menahan dan mengikat curahan air hujan (terdeforestrasi) dan mengakibatkan terjadinya bencana alam berupa banjir (galodo) yang membuat penderitaan bagi masyarakat rentan di sekitar kawasan hutan, oleh karena itu dalam aktivitas dan proses serta hasil penegakan hukumnya terhadap kasus ini hendaknya diarahkan pada aturan lingkungan hidup yang menerapkan prinsip-prinsip "Kelestarian Lingkungan" seperti "Prinsip Tanggungjawab Mutlak" (Strict Liability Principle), 
"Prinsip Pencemar/Perusak Membayar" (Polluter Pays Principle), dan sebagainya sehingga kewajiban perbaikan lingkungan menjadi tanggungjawab para pihak yang terlibat dalam kasus tindak pidana illegal logging;

2. Tindak pidana pembalakan liar (illegal logging) secara faktual, terstrukturisasi, dan tersistemasi telah nyata-nyata merugikan kekayaan dan perekonomian negara serta masyarakat secara luas, perbuatan tersebut tidak saja bermakna sebagai tindakan koruptif tetapi juga merupakan perbuatan yang tidak bermoral, tidak jujur, bejat, busuk, buruk, fitual, dan mengandung banyak penyimpangan terhadap akhlak kesucian, oleh karena itu terhadap bukti-bukti material yang diperoleh dan disita negara, sanksi denda dan pembayaran ganti rugi kepada negara dari para terdakwa, serta berbagai harta benda yang disita oleh negara dari para terdakwa karena diduga hasil dari tindak pidana illegal logging sebagian besar agar diarahkan untuk meningkatkan aktivitas, kemampuan, pengetahuan, dan kinerja penegakan hukum kasus-kasus tindak pidana illegal logging;

3. Tindakan koruptif dalam aktivitas illegal logging yang melibatkan para pihak secara aktual, transaktif, invertif, desentif, otogonik, dan atau kekerabatan yang secara faktual telah merusak moral para birokrat dan warga masyarakat agar segera diantisipasi dengan upaya meningkatkan wawasan kearifan lingkungan, wawasan kewaspadaan dan ketahanan nasional, maupun wawasan kebenaran dan keadilan kepada para pihak yang bersangkutan; dan

4. Praktek illegal logging yang selama ini telah banyak merugikan kekayaan dan perekonomian negara maupun masyarakat secara luas maka dalam tindakan yang bersangkutan dengan antisipasi dan penanggulangannya dapat disertakan kebijakan "Reward and Punishment", khususnya dalam penanganan kasus-kasus illegal logging oleh unsur penegak hukum maupun unsur birokrat lainnya. 


\section{Daftar Kepustakaan}

Djohansyah, J. "Legal Anotasi Terhadap Putusan Perkara Illegal Logging Dengan Terdakwa Adelin Lis, Jakarta, 2008.

Husein, Harun M. "Surat Dakwaan: Teknik Penyusunan, Fungsi dan Permasalahan", Rineka Cipta, Jakarta, 2005.

Indonesian Corruption Watch (ICW), "Hasil Eksaminasi Publik oleh Dr. Djohanes Djohansyah. Dkk", Jakarta, Nopember, 2008.

Kejaksaan Agung RI, "Pedoman Pembuatan Surat Dakwaan", Jakarta, 1985.

Mahkamah Agung RI, "Putusan Peradilan Kasasi atas Kasus Perkara Illegal Logging dengan terdakwa Adelin Lis", Djoko Sarwoko (Juru Bicara MA), Jakarta, 1 Agustus 2008.

Polda Sumatera Utara, Resume Pemeriksaan Kasus Perkara Adelin Lis, Direktorat Reserse Kriminal, Medan, 9 Februari 2007.

Putusan Pengadilan Negeri Medan, Nomor: 2240/Pid.B/2007/PN.MDN, tanggal 5 Nopember 2007, An terdakwa Adelin Lis.

Soedarsono, Teguh. "Mekanisme Jasa Asuransi Sebagai Sarana Penerapan Aspek Hukum Prinsip Tanggungjawab Mutlak (Strict Liability Principle) Dalam Sistem Hukum Lingkungan Nasional", Percetakan Mallya Angkasa, Cetakan Kedua, Jakarta, 2005.

Tuntutan Pidana Kejaksaan Negeri Medan, Nomor: Register Perkara: PDS03/N.2.10/Ft.1/03/2007, tanggal 22 Oktober 2007. 